Нетепчук B. B. [1; ORCID ID: 0000-0002-5210-3373], ст. викладач, Заслужений працівник освіти України

${ }^{1}$ Національний університет водного господарства та природокористування, м. Рівне

\title{
МОДЕЛЬ БІЗНЕС-ПРОЦЕСУ «УПРАВЛЯТИ ЯКІСТЮ» У ФОРМАТІ IDF
}

Еволюція розвитку підходів до вдосконалення результатів операційної діяльності підприємства і прагнення менеджменту оптимізувати співвідношення ціна/якість продукції веде управлінську думку до «створення і забезпечення результативного функціонування системи якості, що включає необхідні організаційну структуру, процедури, процеси і ресурси» [2].

Метою написання статті є огляд функцій процесу управління якістю, методологічний аналіз вимог та рекомендацій стандартів серії ISO 9000 щодо розробки, функціонування і вдосконалення системи управління якістю, а також розробка у форматі IDF 0 моделі «Системи управління якістю» як сукупності бізнес-процесів.

Проведений автором огляд змісту функцій бізнес-процесу «Управляти якістю», аналіз вимог та рекомендацій стандартів серії ISO 900 щодо розробки і функціонування системи менеджменту якістю дав можливість змоделювати їі у формі бізнес-процесу відповідно до вимог нотації IDFO, ідентифікувати та описати основні продукти її функціонування та виконати декомпозицію цього бізнес-процесу у вигляді ланцюжка бізнес-процесів: визначити зміст системи менеджменту якості, планувати систему менеджменту якості, забезпечити функціонування системи менеджменту якості, контролювати стан якості, усувати невідповідності та покращувати систему менеджменту якості. Наведений у статті алгоритм декомпозиції бізнеспроцесу «Управляти якістю» дозволяє системно представити проміжні та результуючі продукти бізнес-процесів системи менеджменту якості, проводити вимірювання стану системи менеджменту якості і впливати на iі результативність та ефективність через управлінські рішення, що прийняті на підставі документованих даних та інформації про стан управління якістю.

Ключові слова: якість; управляти якістю; система менеджменту якості; модель; бізнес-процес; стандарт; ISO; принципи менеджменту якості; графічна мова IDF.

Постановка проблеми. Зростання актуальності проблем якості продукції є результатом розвитку ринкових законів економіки, науки і техніки, технологій товарного виробництва і сервісу. Це 122 
проявляється потребою розробки спеціальних методів в управлінні якістю на підприємствах через ускладнення виробничих процесів; потребою узгодження вимог до якості продукції, що експортується, при одночасному поглибленні галузевої і міжгалузевої спеціалізації та кооперування, розвитку міжнародної торгівлі і технікоекономічної співпраці між країнами; стає надзвичайно актуальним забезпечення однорідності основних параметрів у кожному виробі та забезпечення необхідного рівня якості продукції при збільшенні програм випуску однорідної продукції, що вимагає застосування особливих заходів в управлінні якістю; піднімає рівень вимог до якості товарів і послуг споживчого ринку.

Підвищення якості вимагає додаткових затрат, але гарантоване забезпечення якості товарної продукції створює додану ринкову споживчу цінність і дозволяє повніше задовольняти потреби споживчого ринку і покращувати фінансові результати діяльності підприємства.

Постановка завдання. Метою написання статті $\epsilon$ методологічний аналіз вимог стандартів серії ISO до розробки і удосконалення систем управління якістю та на основі результатів аналізу розробити у форматі IDFO модель системи управління якістю у вигляді сукупності бізнес-процесів.

Аналіз останніх досліджень і публікацій. Перевірка і контроль якості продукції, що випускається бере початок з 1905 року, коли з'явилася система Ф. Тейлора. Завдяки їй у виробничу практику ввійшли поняття «верхня та нижня межа якості», «поле допуску», технічні засоби вимірювання допуску у формі прохідних та непрохідних калібрів. 3 20-х до 50-х рр. XX ст. активно розробляли методи статистичного контролю якості, формувався інструментарій вибіркового контролю, розвивався менеджмент орієнтований на відповідність продукції своєму функціональному призначенню та попередньо обумовлених до неї вимог. 3 визнанням на світовому ринку успіхів економіки Японіі, управлінські думки у сфері якості створили менеджмент орієнтований на об'єкт - на задоволення потреб і запитів конкретного замовника, які є більш широкими ніж обов'язкові вимоги законодавства. Менеджмент переніс акцент на управління маркетингом, вивчення і задоволення споживчого попиту. На початку 1980-х рр. почався перехід від всеосяжного контролю якості до всеосяжного менеджменту якості (TQM). Менеджмент став орієнтованим на покращення. З'явилася серія міжнародних стандартів ICO 9000. У 21-му столітті основою менеджменту якості $\epsilon$ інтеграція всіх ресурсів для досягнення 
поставлених цілей, висока творча віддача і безперервне покращення як частина робочого процесу. Споживач стає все більш вибагливим до надійності, довговічності, стабільності характеристик товару в різних умовах експлуатації, ставить додаткові вимоги безпеки товару. Все це потребує нових підходів до побудови та впровадження СУЯ з врахуванням менталітету, культури та інших особливостей споживача.

Питання управління якістю продукції розглянуті в працях багатьох вітчизняних та зарубіжних науковців, зокрема: Демінга Е., Фейгенбаума А., Ісікави К., Лапідуса В., Адлера Ю., Глічева А., Гудзя П., Харрінгтона Дж. та інших. У сучасних умовах загострення конкуренції та підвищення вимог споживачів до товарів та послуг виникає нагальна необхідність аналізу питань щодо удосконалення процесу управління якістю продукції, формування та впровадження системи управління якістю на підприємствах, що $€$ актуальним в умовах виходу на зовнішні ринки і адаптації до міжнародних стандартів.

Виклад основного матеріалу. Загальні вимоги до розробки і впровадження системи менеджменту якості (СМЯ) описано у стандарті [3], а рекомендації щодо ії розвитку та безперервного задоволення потреб і очікувань зацікавлених сторін з дотриманням відповідного балансу в довгостроковій перспективі у стандарті [4]. Стандарт [5], що містить основні положення систем управління якістю і визначає термінологію для них, наголошує, що система менеджменту якості - це сукупність взаємопов'язаних або взаємодіючих елементів організації для формування політик і цілей, а також процесів для досягнення цілей у сфері якості.

Розглядаючи основні принципи менеджменту якості слід зазначити, що у науковій літературі існує кілька підходів до розгляду та з'ясування сутності принципів менеджменту якості. Перший - це принципи, сформульовані Е. Демінгом, що мають не методологічний, а швидше прагматичний характер. Фактично, це установки чи постулати щодо формування поведінки менеджерів для досягнення цілей у сфері якості.

Другий підхід орієнтовано на розгляд змісту сучасних принципів менеджменту якості, визначених стандартом ISO 9000:2015 [5]:

-Залучення персоналу - люди є основою організації, повне залучення їхніх можливостей сприяє досягненню цілей. Компетентний, правоздатний та задіяний персонал на всіх рівнях в 
організації - суттєво важливий для покращення спроможності організації створювати цінність.

- Процесний підхід - система управління організацією будується на основі управління мережею процесів і складається із взаємопов'язаних процесів.

-Поліпшення виступає стратегічною метою діяльності організації. Успішні організації постійно зорієнтовані на поліпшення, щоб підтримувати поточні рівні дієвості, реагувати на зміни в ії внутрішніх і зовнішніх умовах, а також, щоб створити нові можливості.

-Прийняття рішень на підставі фактичних даних. Прийняття рішень може бути складним процесом і охоплювати чимало видів і джерел вхідних даних, а також їх інтерпретацію, яка може бути суб'єктивною і містити деяку невизначеність. Ефективні рішення базуються на логічному аналізі й раціональному оцінюванні інформації та первинних даних, що створює більшу ймовірність уможливити бажані результати, більшу об'єктивність і впевненість у прийнятті рішень.

-Лідерство - лідери визначають напрями дій, на всіх рівнях установлюють єдність призначеності та напрямків розвитку і створюють умови для задіяння персоналу до досягнення цілей організації у сфері якості [5]. Це дає змогу організації узгоджувати свої стратегії, політики, процеси та ресурси, створити середовище, у якому люди можуть бути цілком задіяні для досягнення цілей.

- Орієнтація на споживача - організація має розуміти дійсні та майбутні потреби споживача та інших зацікавлених сторін, задовольняти їхні вимоги й намагатися перевершити їхні очікування. Це сприяє сталому успіху організації. Сталого успіху досягають, якщо організація привертає та утримує довіру замовників й інших відповідних зацікавлених сторін [5].

- Керування взаємовідносинами. Взаємовигідні відносини 3 постачальниками посилюють можливості обох сторін у створенні цінності. Сталого успіху з більшою ймовірністю досягають, якщо організація керує взаємовідносинами зі всіма своїми зацікавленими сторонами, щоб оптимізувати їхній вплив на свою дієвість.

Система управління якістю керує взаємодійними процесами і ресурсами, що потрібні для створення споживчої цінності і здобуття результатів для відповідних зацікавлених сторін. Формалізована СМЯ $\epsilon$ основою для планування, виконання, моніторингу i покращення діяльності менеджменту підриємства. Об'єктами 
управління якістю $\epsilon$ продукція і процеси, які у стандарті [6] згруповані наступним чином (рис. 1):

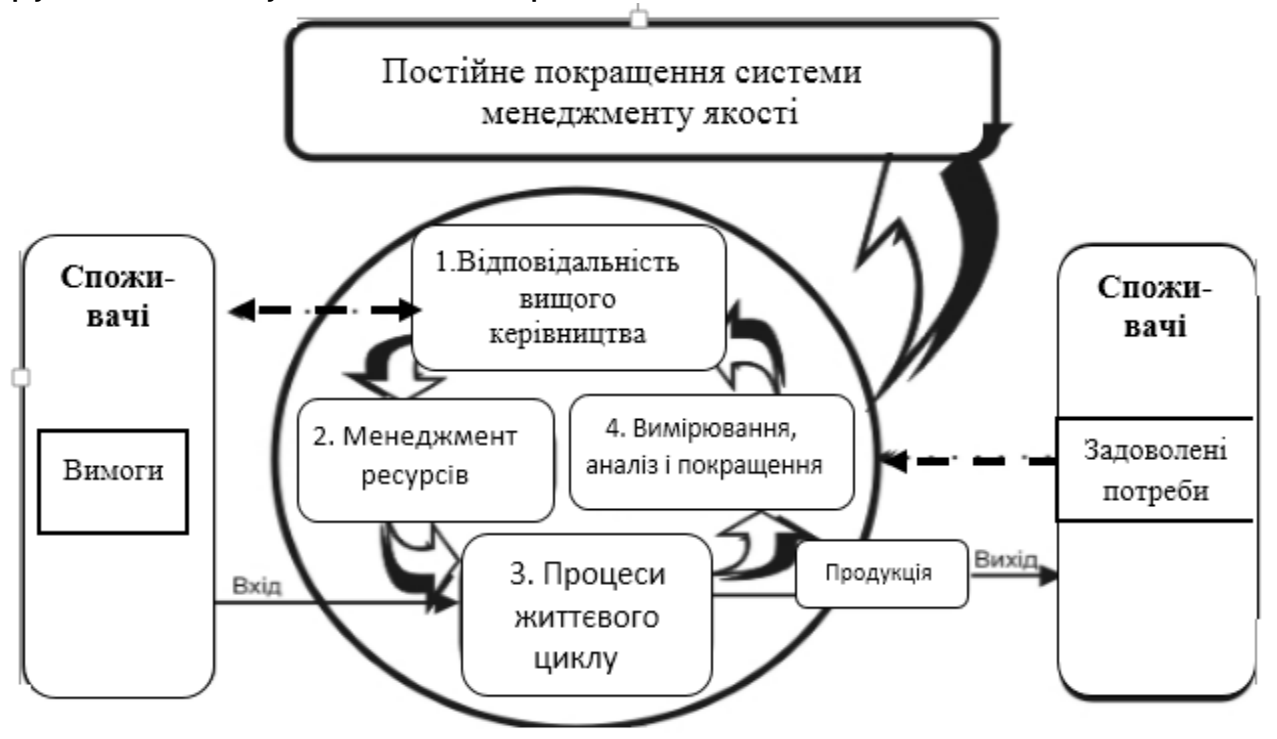

Рис. 1. Групи процесів системи менеджменту якості

Стандарти [3; 7] містять вимоги і пояснення щодо переліку i змісту процесів Системи менеджменту якості, що відображені на рис. 1:

1. Відповідальність вищого керівництва (група процесів управління):

- визначення сфери застосування системи управління якістю (п. 4.3);

- визначення процесів, що потрібні для системи управління якістю і застосування документованої інформації для забезпечення їх функціонування (п. 4.4);

- визначення функцій, повноважень і відповідальності вищого керівництва щодо результативності СМЯ (п. 5.1);

- розробка і реалізація політики у сфері якості (п. 5.2);

- визначення функцій, повноважень і відповідальності персоналу організації (п. 5.3);

- планування дій стосовно ризиків і можливостей (п. 6.1);

- визначення цілей у сфері якості і планування їх досягнення (п. 6.2);

- планування змін СМЯ із врахуванням факторів середовища організації (п. 6.3);

-визначення алгоритму щодо внутрішнього та зовнішнього обміну інформацією (п. 7.4); 
- планування і управління діяльністю за етапами життєвого циклу продукції і послуг (п. 8.1).

\section{забезпечення):}

2. Менеджмент ресурсів (група процесів ресурсного

- визначення і забезпечення наявності працівників (п. 7.1.2);

- визначення, створення і підтримка інфраструктури (п. 7.1.3);

- визначення, створення і підтримка середовища для функціонування процесів (п. 7.1.4);

- визначення і надання ресурсів для моніторингу і вимірювання якості процесів, продукції і послуг (п. 7.1.5);

- визначення, підтримка і надання знань для функціонування процесів і досягнення відповідності продукції та послуг (п. 7.1.6);

- визначення і забезпечення необхідної компетентності (п. 7.2);

- визначення поінформованості та обізнаності персоналу у сфері якості (п. 7.3);

- створення, актуалізація і управління документованою інформацією (п. 7.5).

3. Процеси життєвого циклу продукції (група основних процесів):

- визначення вимог до продукції та послуг (п. 8.2.2);

- проєктування та розроблення продукції та послуг (п. 8.3);

- контроль надаваних із зовні процесів, продукції та (п. 8.4);

- виготовлення продукції та надання послуг (п. 8.5);

- відвантаження продукції та послуг (п. 8.6);

- контроль невідповідних виходів (п. 8.7).

4. Вимірювання, аналіз і покращення (група процесів інформаційно-аналітичного забезпечення управління і розвитку):

- визначення, моніторинг і аналіз факторів зовнішнього і внутрішнього середовища організації (п. 4.1);

- визначення моніторинг i аналіз потреб та очікувань зацікавлених сторін (п. 4.2);

- моніторинг, вимірювання, аналіз і оцінка результатів діяльності (п. 9.1);

- внутрішній аудит якості (п. 9.2);

- аналіз СМЯ з боку вищого керівництва (п. 9.3);

- визначення можливостей для покращення діяльності і результативності СМЯ (п. 10.1);

- усунення невідповідностей і коригуючі дії (п. 10.2);

- безперервне покращення діяльності (п. 10.3).

Основний перелік робіт з розробки СМЯ включає проведення самооцінки стану менеджменту (визначення сильних і слабких 
сторін у підприємства) і коригування бачення змісту СМЯ відповідно до отриманих результатів; формулювання вищим керівництвом політики і цілей у сфері якості; розробку системи бізнес-процесів, що описують зміст діяльності підприємства; визначення та документований опис процесів, що забезпечують якісне управління, розробку і затвердження документації СМЯ (настанови з якості, стандарти, методики, інструкції тощо). Зазначена сукупність дій орієнтована на створення продуктів діяльності бізнес-процесу «Управляти якістю», які ми відобразимо на моделі бізнес-процесу, що розроблена у форматі IDF 0 (рис. 2).

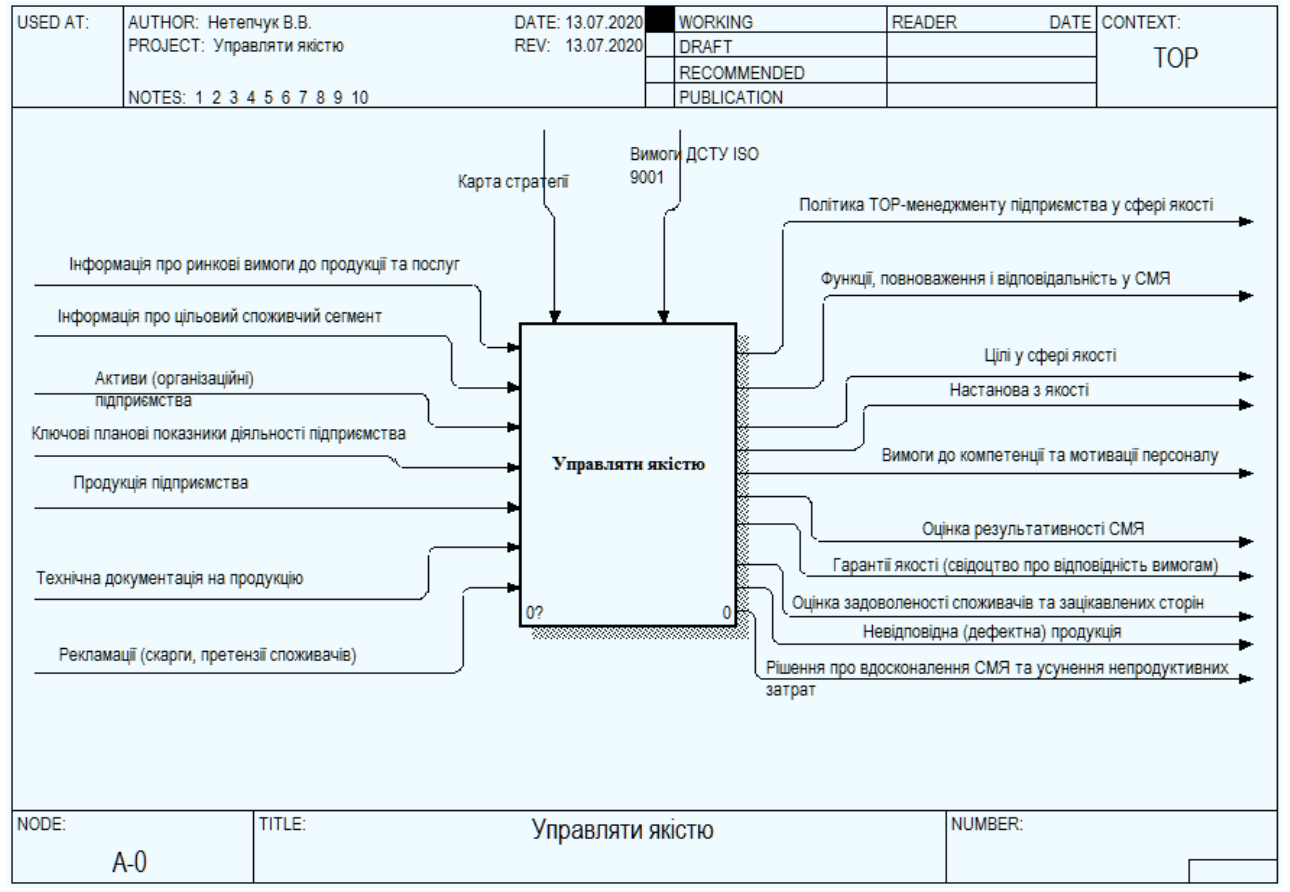

Рис. 2. ТОР модель бізнес-процесу «Управляти якістю» (автор)

У стандарті [3] відсутній конкретний опис вимог до змісту дій менеджменту організації, що необхідно виконати в межах процесу «Управляти якістю». Але, у стандарті [5] пункти 3.3.5-3.3.8 у свої послідовності і змісті описують процес «Управляти якістю» згідно із вимогами циклу Е. Демінга: «плануй-дій-перевіряй-коригуй». Даний цикл фахівці у сфері якості розглядають як спрощений алгоритм дій керівника стосовно управління процесами і досягнення мети, показану на рис. 3. 


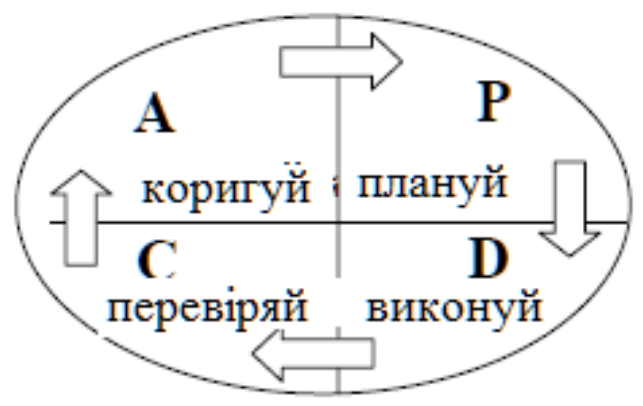

Рис. 3. Циклічна модель управління якістю Е. Демінга

Для визначення змісту кожного із кроків циклу Е. Демінга проаналізуємо зміст понять і термінів, що їх наводить стандарт [5]:

- планування якості (quality planning) - складова частина управління якістю, зосереджена на встановленні цілей у сфері якості та на визначенні операційних процесів і відповідних ресурсів, необхідних для досягнення визначених цілей у сфері якості;

- забезпечування якості (quality assurance) - складова частина управління якістю, зосереджена на створенні впевненості в тому, що вимоги щодо якості буде виконано;

- контролювання якості (quality control) - складова частина управління якістю, зосереджена на виконанні вимог щодо якості;

- поліпшування якості (quality improvement) - складова частина управління якістю, що зосереджена на збільшенні здатності виконувати вимоги щодо якості. Вимоги щодо якості можуть бути пов'язані 3 будь-яким 3 таких аспектів, як результативність, ефективність чи простежуваніть.

Універсальний класифікатор процесів для різних галузей американського центру продуктивності і якості змісту процесу «Управляти якістю на підприємствах» описує структуру процесу «Управляти якістю» у послідовності бізнес-процесів:

1. Створити вимоги до якості (визначення характеристик, критичних до якості; визначення профілактичних заходів забезпечення якості; перевірка відповідності плану якості; перевірка можливостей забезпечення відповідності вимогам; затвердження плану якості).

2. Оцінити дотримання вимог (перевірка відповідності плану якості; оцінка результатів випробувань).

3. Управляти невідповідностями (оцінка потенційного впливу; 
визначення негайних заходів; визначення причин; усунення або прийняття превентивних заходів; усунення невідповідності).

4. Впроваджувати і підтримувати систему управління якістю на підприємстві (визначення стратегії управління якістю (планування та розгортання спеціалізованого програмного забезпечення для системи управління якістю; визначення ключових процесів системи управління якістю, органів управління і показників; розробка і документування регламентів, процедур, стандартів і показників управління якістю; оцінка продуктивності системи управління якістю; створення оточення і компетенцій для поліпшення системи управління якістю.

У Національному Стандарті України ДСТУ ISO/IEC/IEEE 15288:2016 (ISO/IEC/IEEE 15288:2015, IDT): «Інженерія систем і програмного забезпечення. Процеси життєвого циклу систем» [7] наводиться текстовий опис бізнес-процесу «Управляти якістю», що має мету - забезпечити відповідність продуктів, послуг і реалізації процесу управління якістю організаційним, проєктним цілям управління якістю та досягнення задоволеності замовника.

Стандарт [7] передбачає отримати внаслідок реалізації процесу «Управляти якістю» вихідні результати (виходи): а) організаційні цілі управління якістю, політика і процедури; b) критерії та методи оцінки якості; с) ресурси й інформація для підтримки функціонування і контролю дій щодо забезпечення гарантії якості проєктів; d) дані про результати оцінки забезпечення якості; е) поліпшення політики управління якістю та процедури, засновані на проєктних і організаційних результатах.

Для отримання зазначених результатів вищезазначений стандарт [7] рекомендує виконати згідно із вимогами затвердженої політики у сфері якості наступний перелік процедур:

а) планувати управління якістю (визначати зобов'язання і повноваження для реалізації управління якістю; визначати критерії і методи оцінки управління якістю; забезпечувати ресурсами та інформацією для управління якістю);

b) оцінювати управління якістю (збирати і аналізувати результати оцінки забезпечення гарантій якості відповідно до визначених критеріїв; оцінювати задоволеність замовника; проводити періодичні аналізи дій щодо забезпечення якості проєкту для узгодження з цілями управління якістю організації, з політикою і процедурами; контролювати статус поліпшень якості для процесів, продуктів і послуг); 
с) виконати коригувальні та попереджувальні дії з управління якістю (планувати коригувальні дії, коли цілі управління якістю не досягнуті; планувати превентивні заходи, коли $є$ ризик того, що цілі управління якістю не будуть досягнуті; здійснювати коригувальні дії та повідомляти про них відповідним зацікавленим сторонам).

За результатами проведеного аналізу вимог, рекомендацій i настанов стандартів серії ISO 9000 можна зробити висновок, що розробка і впровадження системи управління якістю здійснюється згідно із циклом Н. Демінга. Результатом успішного впровадження і функціонування СУЯ $є$ наступний перелік результуючих продуктів, що підтверджує результативність системи управління:

- політика ТОР менеджменту підприємства у сфері якості,

- функції, повноваження і відповідальність у СМЯ,

- цілі у сфері якості,

- настанова з якості,

- вимоги до компетенції та мотивації персоналу,

- оцінка результативності СМЯ,

- оцінка задоволеності споживачів та зацікавлених сторін,

- гарантії якості (свідоцтво про відповідність вимогам),

- невідповідна (дефектна) продукція,

- рішення про вдосконалення СМЯ та усунення непродуктивних затрат.

Для отримання зазначеного переліку результуючих продуктів 3 розробки i функціонування суя менеджмент компанії має забезпечити виконання рекомендованої послідовності бізнеспроцедур, що дозволить отримати проміжні продукти діяльності, які слугуватимуть входами для отримання бажаного кінцевого результати, - забезпечити відповідність продуктів, послуги i реалізації процесу управління якістю організаційним, проєктним цілям управління якістю та досягнення задоволеності замовника. Логічний зв'язок між процедурами і продуктами бізнес-процесу «Управляти якістю» відобразимо шляхом декомпозиції процесу, що зображено на рис. 4. 


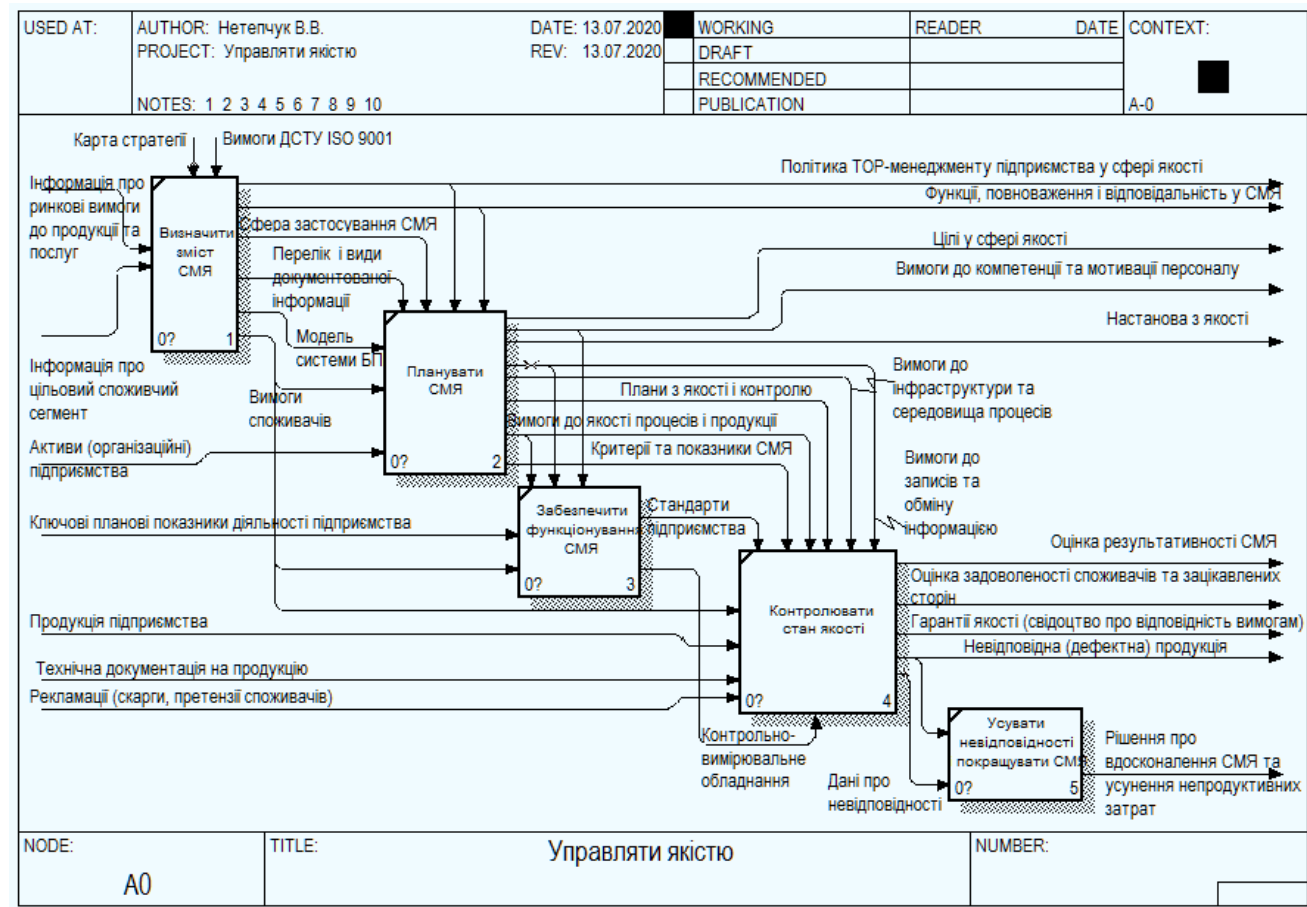

Рис. 4. Модель декомпозиції процесу «Управляти якістю» у нотації IDEF 0

Розробку моделі проводимо 3 допомогою програмного забезпечення AllFusion Process Modeler 7 у форматі IDF 0 ).

Висновки. Методологічний аналіз вимог стандартів серії ISO до розробки і удосконалення систем управління якістю дозволив визначити перелік і зміст бізнес-процесів, зміст результуючих та проміжних продуктів, вхідних потоків та регламентів, що деталізують зміст робіт з розробки і функціонування системи управління якістю. Візуалізація моделі системи управління якістю 3 допомогою програмного забезпечення AllFusion Process Modeler7 дозволяє комплексно і сконцентровано представити всю сукупність робіт 3 розробки і підтримання системи управління якістю, провести опис вимог до змісту всіх ї̈ елементів і перейти до формування організаційно-структурних карт та стандартів бізнес-процесів і процедур згідно із вимогами ДСТУ ISO 9001:2015 (ISO 9001:2015, ID): «Системи управління якістю. Вимоги». Наведений у статті алгоритм декомпозиції бізнес-процесу «Управляти якістю» дозволяє системно представити проміжні та результуючі продукти бізнес-процесів системи менеджменту якості, проводити вимірювання стану системи менеджменту якості і впливати на їі результативність та ефективність через управлінські рішення, що прийняті на підставі документованих даних та інформації про стан управління якістю. Це створює можливість знизити невизначеність у прийнятті рішень, 
оскільки документований опис вимог до протікання бізнес-процесів, до змісту проміжних і результуючих продуктів процесу розробки функціонування СУя дозволяє зменшити трансформацію інформації та скоротити часовий період і фінансові затрати на її впровадження.

1. Нетепчук В. В. Управління бізнес-процесами: навч. посібник. Рівне : НУВГП, 2014. 158 с. 2. ISO 9004-1-94, частина 1. Адміністративне управління якістю і елементи системи якості, частина 1. Керівні вказівки. Київ : ДП «УкрНДНЦ», 1994. 3. ДСТУ ISO 9001:2015 (ISO 9001:2015, ID). Системи управління якістю. Вимоги. Київ, ДП «УкрНДНЦ», 2016. 4. ДСТУ ISO 9004:2018. Управління якістю. Якість організації. Настанови щодо досягнення сталого успіху (ISO 9004:2018, IDT). Київ, ДП «УкрНДНЦ», 2018. 5. ДСТУ ISO 9000:2015 (ISO 9000:2015, IDT). Системи управління якістю. Основні положення та словник термінів. Київ, ДП «УкрНДНЦ», 2016. 6. ДСТУ ISO 10005:2007. Настанови щодо програм якості. Київ : Держспоживстандарт України, 2008. 7. ДСТУ ISO/IEC/IEEE 15288:2016 (ISO/IEC/IEEE 15288:2015, IDT). Інженерія систем і програмного забезпечення. Процеси життєвого циклу систем. Київ : ДП «УкрНДНЦ», 2018. 8. ДСТУ ISO 9004-2001. Системи управління якістю. Настанови щодо поліпшення діяльності. Київ, ДП «УкрНДНЦ», 2001. 9. Нетепчук В.В. Управління якістю: інтерактивний комплекс навчальнометодичного забезпечення. Рівне : НУВГП, 2007. 134 С.

\section{REFERENCES:}

1. Netepchuk V. V. Upravlinnia biznes-protsesamy : navch. posibnyk. Rivne : NUVHP, 2014. 158 s. 2. ISO 9004-1-94, chastyna 1. Administratyvne upravlinnia yakistiu i elementy systemy yakosti, chastyna 1. Kerivni vkazivky. Kyiv : DP «UkrNDNTs», 1994. 3. DSTU ISO 9001:2015 (ISO 9001:2015, ID). Systemy upravlinnia yakistiu. Vymohy. Kyiv, DP «UkrNDNTs», 2016. 4. DSTU ISO 9004:2018. Upravlinnia yakistiu. Yakist orhanizatsii. Nastanovy shchodo dosiahnennia staloho uspikhu (ISO 9004:2018, IDT). Kyiv, DP «UkrNDNTs», 2018. 5. DSTU ISO 9000:2015 (ISO 9000:2015, IDT). Systemy upravlinnia yakistiu. Osnovni polozhennia ta slovnyk terminiv. Kyiv, DP «UkrNDNTs», 2016. 6. DSTU ISO 10005:2007. Nastanovy shchodo prohram yakosti. Kyiv : Derzhspozhyvstandart Ukrainy, 2008. 7. DSTU ISO/IEC/IEEE 15288:2016 (ISO/IEC/IEEE 15288:2015, IDT). Inzheneriia system i prohramnoho zabezpechennia. Protsesy zhyttievoho tsyklu system. Kyiv : DP «UkrNDNTs», 2018. 8. DSTU ISO 9004-2001. Systemy upravlinnia yakistiu. Nastanovy shchodo polipshennia diialnosti. Kyiv, DP «UkrNDNTs», 2001. 9. Netepchuk V. V. Upravlinnia yakistiu : interaktyvnyi kompleks navchalno-metodychnoho zabezpechennia. Rivne : NUVHP, 2007. 134 s. 
Netepchuk V. V. [1; ORCID ID : 0000-0002-5210-3373], Senior Lecturer, Honored Worker of Education of Ukraine

${ }^{1}$ National University of Water and Environmental Engineering, Rivne

\section{MODEL OF «QUALITY MANAGEMENT» BUSINESS PROCESS IN IDF FORMAT}

The evolution of approaches to improving the results of the enterprise operating activity and the desire of management to optimize the price I quality interrelation leads management to «creating and ensuring the effective functioning of the quality system, including the necessary organizational structure, procedures, processes and resources».

The purpose of this article is to review the functions of the quality management process, methodological analysis of the requirements and recommendations of ISO 9000 series standards for the development, operation and improvement of quality management system and development in the model IDFO «Quality Management Systems» as a set of business processes.

The author's review of the content of business process functions «quality management», analysis of requirements and recommendations of ISO 900 series standards for the development and operation of quality management system created an opportunity to model it as a business process according to IDFO, identify and describe the main products of its operation and perform decomposition of this business process in the form of a chain of business processes: determine the content of the quality management system, plan the quality management system, ensure the functioning of the quality management system, comtrol the quality, eliminate inconsistencies and improve the quality management system. The algorithm of decomposition of business processes «quality management», presented in the article, allows you to systematically present intermediate and result products of business processes of quality management system, measure the state of quality management system and influence its efficiency and effectiveness through decision management based on documented data and information about the state of quality management.

Keywords: quality; quality management; quality management system; model; business process; standard; ISO; principles of quality management; graphic language IDF $_{0}$. 
Нетепчук B. В. ${ }^{[1 ;}$ ORCID ID: 0000-0002-5210-3373],

ст. преподаватель, Заслуженный работник образования Украины

${ }^{1}$ Национальный университет водного хозяйства и природопользования, г. Ровно

\section{МОДЕЛЬ БИЗНЕС-ПРОЦЕССА «УПРАВЛЯТЬ КАЧЕСТВОМ» В ФOPMATE IDF 0}

Эволюция развития подходов к совершенствованию результатов операционной деятельности предприятия и стремление менеджмента оптимизировать соотношением цена/ качество ведет управленческую мысль до «создания и обеспечения эффективного функционирования системы качества, включая необходимые организационную структуру, процедуры, процессы и ресурсы».

Целью написания статьи является обзор функций процесса управления качеством, анализ требований и рекомендаций стандартов серии ISO 9000 по разработке, функционировании и совершенствовании систем управления качеством, разработка в формате IDF 0 модели «Системы управления качеством» как совокупности бизнес-процессов.

Проведенный автором обзор содержания функций бизнес-процесса «Управлять качеством», анализ требований и рекомендаций стандартов серии ISO 900 по разработке и функционирования системы менеджмента качеством создал возможность смоделировать ее в форме бизнеспроцесса В соответстви с требованиями нотации IDF идентифицировать и описать основные продукты ее функционирования и выполнить декомпозицию данного бизнес-процесса в виде цепочки бизнес-процессов: определить содержание системы менеджмента качества, планировать систему менеджмента качества, обеспечить функционирование системы менеджмента качества, контролировать состояние качества, устранять несоответствия и улучшать систему менеджмента качества.

Приведенный в статье алгоритм декомпозиции бизнес-процесса «управлять качеством» позволяет системно представить промежуточные и результирующие продукты бизнес-процессов системы менеджмента качества, проводить измерения состояния системы менеджмента качества и влиять на ее результативность и эффективность через управленческие решения, принятые на основании документированных данных и информации о состоянии управления качеством.

Ключевые слова: качество; управлять качеством; система меенджмента качества; модель; бизнес-процесс; стандарт; ISO; принципы менеджмента качества; графический язык $\mathrm{IDEF}_{0}$. 